
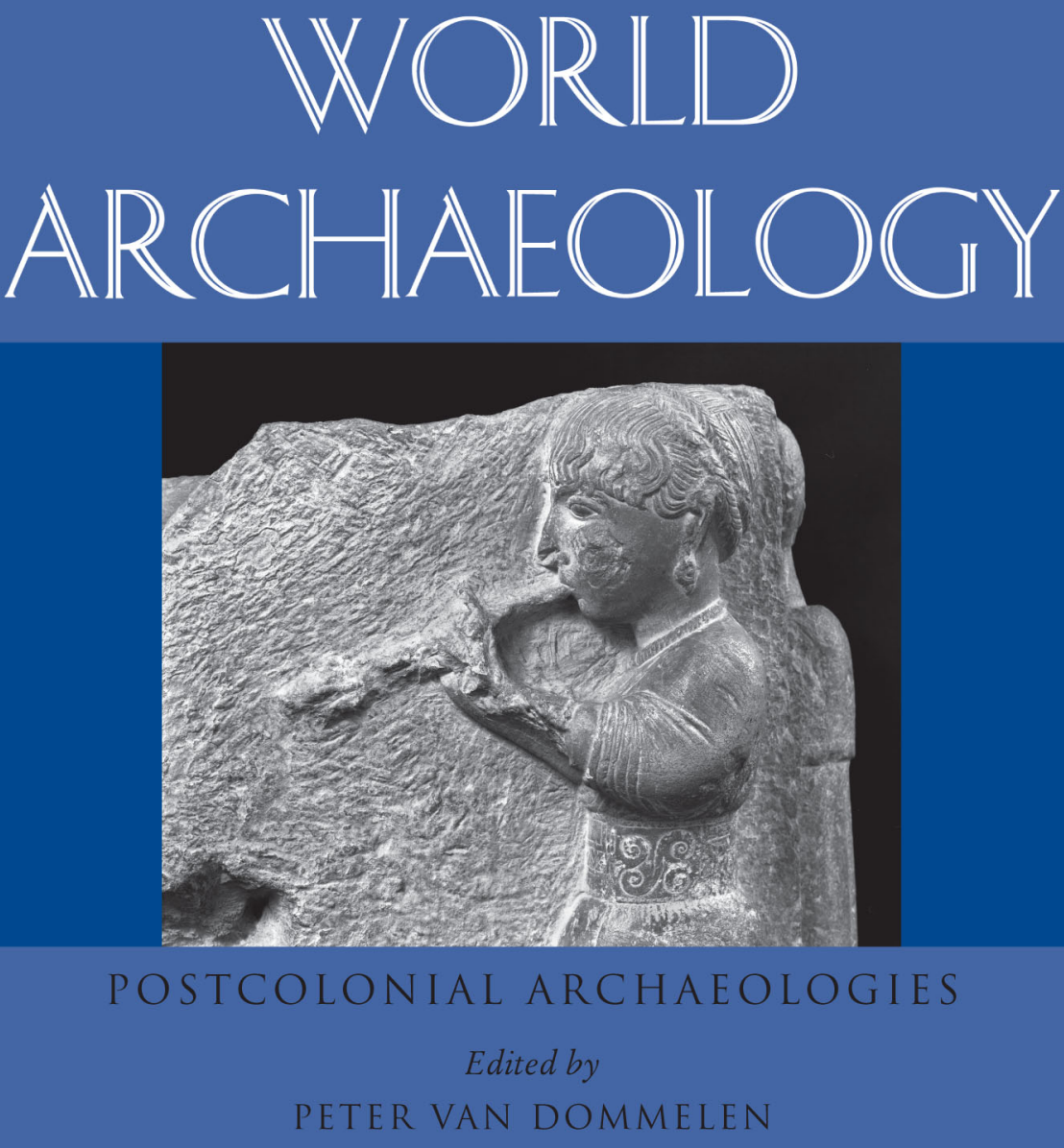

Routledge
Taylor \& Francis Croup
喽

VOLUME FORTY THREE • NUMBER 1 • MARCH 2011 


\title{
Pure hybridism: Late Iron Age sculpture in southern Iberia
}

\author{
Alicia Jiménez
}

\begin{abstract}
The concept of hybridism has its origins in the natural sciences and was important in nineteenthcentury debates about race. Nowadays it is especially relevant to various disciplines of the social sciences in connection with issues such as globalization, transnational dynamics, postcolonial diasporas and multiculturalism. 'Hybridism' has been recently introduced into archaeological literature, only to risk becoming an overly simple explanation of changes in material culture if deprived of its theoretical background. If material culture is hybrid by definition, what are the advantages of using the word 'hybrid' to describe it? In this paper I test the value of hybridism as a useful concept in approaching local reinterpretations of exogenous objects and the influence of Roman colonialism in local contexts, using as a case study Late Iron Age sculptures (third to first centuries BC) from the south and the east of the Iberian Peninsula.
\end{abstract}

\section{Keywords}

Hybridism; colonization; postcolonialism; cultural difference; 'third space'; Late Iron Age sculpture.

\section{Hybrid origins: race and culture}

The English word 'hybrid' comes from the Latin hybrida, used in antiquity to refer not only to a half-bred or crossbred animal, but also to the descendants of human progenitors, specifically the offspring of Romans and slaves or Romans and foreigners (OLD 1982). This notion was also used in the modern age in relation to the progeny of a dissimilar, heterogeneous or unlike couple. It later became an important concept in nineteenthcentury debates on race, although the grounds of some of the arguments in the dispute can be already found in the eighteenth century, when different varieties of human beings were included in the animal kingdom as part of the hierarchical scale of the Great Chain of Being (Young 1995: 6). The idea of humans belonging to a different species, which allowed 
the placing in this classification of the African next to the ape at the bottom of the human family, clashed, however, with the biblical account of a single origin shared by the human race. Eighteenth-century naturalists generally accepted the test for distinguishing species developed by the Comte de Buffon in France and John Hunter in Britain: while animals of the same species were considered to be able to reproduce their kind for ever, the product of two different species, the hybrid, was deemed infertile or bound to perish over the course of time. Clear examples of this case were the mule and the hinny, female-male and malefemale crosses of horse and ass respectively. Faced with the impossibility of negating the fertility of the mixed-race population in the colonies, some authors, including Long in his History of Jamaica, compared mulattos to mules and stated that their fertility tended to decline over generations (Long 1774: 335, quoted in Young 1995: 8). Even though Enlightenment views sustaining universality as well as humanitarian and egalitarian ideas prevailed in the debate that opposed the theories of monogenesis (one original species) and polygenesis (many original species), the question of human species and human hybrids was still considered in publications on race as late as the 1970s (Jones 1997: 44; Young 1995: 6-9).

Hybridity thus played an important role in constructing colonialist discourses of racism around the turn of the century. The hybrid was not only a consequence of sex outside the established classificatory and hierarchical order, but also a threatening step towards the creation of 'raceless' groups capable of blurring discrimination sustained by difference (Ashcroft et al. 1998: 120; Vale de Almeida 2002: 182; Young 1995: 19). The categorization of the human mixture as a form of degeneration helped, of course, to assert a norm ultimately based on the assumption of the existence of separate pure fixed categories.

Ideas about racial hybridity were easily translated into cultural history through the interpretation of civilizations as 'living entities' that are born, grow and die. They are found in the work of authors such as Spengler (1918-22), as well as through the application of Lamarckian proposals on the possibility of inheriting cultural characteristics and Darwin's ideas in neo-evolutionist readings of the past. Cultural change was explained mainly through evolutionist or diffusionist models, in which encounters between two cultures resulted in the transformation of the less advanced society according to Western paradigms (Jones 1997: 42-3). Understanding that essentialist categories of cultural identity or race were always culturally derived and that the concepts of race and culture developed together, as Young (1995: 27) has pointed out, is therefore as crucial as remembering that both are enacted in contexts of power and domination (Werbner 1997: 226).

Other concepts usually related to cultural contact have roots that are as deeply colonial as those of hybridism. Terms such as 'pidgin' and 'creole' can be linked through the word criollo to the colonization of the New World by the Portuguese and Spaniards. Both the Spanish criollo and the Portuguese crioulo derive from the Latin creare, the first meaning of which is to procreate, to give birth to. The word was used to refer to animals or humans of pure European descent who were born in the New World and played an important role in the creation of the colonial upper-class, despite being neither pure Europeans nor pure Americans (Anderson 1991: 58; Stewart 1999: 44, 2007: 7). The creolization model has been employed as an analytical tool in studies of contacts between a dominant and a subdominant language. It takes as a starting point the need to communicate beyond linguistic borders and the creation of overlapping or sometimes mutually unintelligible dialects. This explains its later use as a metaphor for understanding transformations in 
culture - including material culture present in the archaeological record - as a result of colonialism, diaspora or contact (Cohen and Toninato 2010; Hannerz 1987: 551-2; Kapchan and Strong 1999: 240-1; Stewart 1999: 42-4, 2007; Webster 2001; contra Palmié 2007; van Dommelen 1998: 31; Wallace-Hadrill 2008: 11-13). The term mestizaje was also formally used in the Spanish empire to refer to people of mixed European (Spanish) and Amerindian ancestry. Today the term has both racial and cultural connotations and plays an important role in nation-building strategies in Latin American countries such as Ecuador, Argentina, Mexico, Brazil, Cuba and Bolivia (Burke 2009: 63; Stewart 1999: 47-8).

Other models have been favoured in further fields of research. This is the case, for example, of syncretism in studies of religion dealing with questions of 'cultural translation' in new contexts. The term had negative overtones in the wake of the Reformation linked to the campaign by the Lutheran theologian Georg Calixtus (1586-1656) to unify the various Protestant groups and the Catholic Church, which gave rise to the so-called 'syncretic controversies'. Colonial churches integrating indigenous elements were also referred to pejoratively as 'syncretic' (Stewart 1999: 45-6). This concept, which mainly highlights adaptation and assimilation, was central to some anthropology. It appears prominently, for example, in Herskovits' (1966) analysis of the combination of African and Christian practices among the Vodoun. He was not only intrigued by the presence of foreign traits in local contexts, but also by the very logic that leads to the adoption of some traits and the dismissal of others. According to Herkskovits, in conditions of contact and displacement, the cultural forms that most resemble each other are kept and re-elaborated, while those that differ the most are usually lost, although in cases where they are dominant in the original environment, they can be reinterpreted to fit the new context.

Most of these ideas about social and cultural interaction have been revisited as a consequence of the widespread critique in contemporary social theory of old models of 'cultures' conceived as stable, homogeneous and bounded entities transmitted unchanged across generations (for example, Barth 1989; Clifford 1988; Rosaldo 1989). In parallel, an increasing interest in the cultural aspects of globalization, transnational identities and diaspora is resulting in the reassessment of previous Eurocentric models of cultural change. Earlier analytical tools were based on mainly centre-periphery theories that were unable to explain the complexities of the overlapping and disjunctive order of a world defined by the transgression of boundaries established by the nation-state (Appadurai 1996: 32; Gikandi 2005: 614-15; Hannerz 1987: 555-7; Stewart 1999: 40).

Inevitably, disrupting old notions of cultural boundaries has also had consequences for concepts clinging to the margins, such as hybridism. How can hybridization processes be understood in new terms when even attempting to conceptualize hybridism requires accepting the existence of once pure, distinct cultures? And if we abandon the thought of the existence of 'essentialist cultures' for the idea of the essentially hybrid nature of all cultural productions, what is the point of even thinking about hybridism? At this point, asserting that all cultures and languages are hybrids is at best a facile truism (Friedman 1997: 73, 1999: 249). ${ }^{1}$

Positive views of mixture, mestizaje, the melting pot or hybridism have been critically reevaluated and accused of hiding an 'invitation to whiteness' or of fulfilling the teleological mission of syncretism: assimilation and cultural homogenization (Stewart 1999: 48, n. 8). Only too often discourses on miscegenation and hybridity, presented as a simple cultural 
'exchange', have masked not only cultural and social differences, but also the imbalance of power relations in many contact situations (Ashcroft et al. 1998: 119; Vale de Almeida 2002: 181). Moreover, critics of postcolonial approaches, such as Parry (1987: 43) and Ahmad (1995: 12-13, 17), have come out against an ahistorical view of hybridity focusing exclusively on literary discourses that neglects the material realities and social practices of colonialism, as well as the real conditions of existence in the globalized postcolonial world. Hybridity has been linked to the views of a 'new cosmopolitan elite' who share a certain loss of rootedness and position themselves under the common flag of anti-nationalism that cannot be so readily imposed on the vast majority of immigrants (Ahmad 1992: 207-8, 1995: 13; Friedman 1997: 72, 1999: 237).

\section{Mixed media: some examples of Late Iron Age sculpture from the Iberian Peninsula}

Past and present discourses on hybridity are not, of course, transmitted only through the written word. However, archaeological studies of ancient colonialism, such as those dealing with the Roman expansion across the Mediterranean, have been, and still are, to a large extent mediated by Graeco-Roman literary representations of the conquest, which in most cases present integration into the Roman empire as a positive element for the conquered peoples (Dueck 2000: 115-22; Lomas 1996: 46). Leaving that aside, hybridism as an analytical tool has similar faults and advantages for archaeology as it has for other disciplines, although the focus on the material reality of colonial contexts offers the possibility of counterbalancing in certain cases one-sided analyses based only on elite practices such as writing. The Late Iron Age or Late Republican sculpture of the Mediterranean regions of the Iberian Peninsula offers an interesting example (Fig. 1). Chronologically, studies of these statues are placed on the awkward margins where scholars from two disciplines meet: Spanish prehistorians interpret this late expression of Iberian art as decadent in comparison to the fine sculptures dated to the fifth and fourth centuries BC, whereas classicists are mainly concerned with tracing the introduction of a 'truly' Roman art into Hispania. These statues have been explicitly regarded as a case of hybridism and have been linked to a bilingual artistic language characteristic of the period of the Roman conquest, which expanded over two hundred years of the Late Republic (Beltrán 2009: 38; Jiménez 2008: 157; Noguera 2003: 164, 196; Noguera and Rodríguez Oliva 2008: 381; Rodríguez Oliva 1996: 14, 2001-2: 308).

In fact, the earliest known examples of Iberian sculpture, which are dated to the end of the sixth and early fifth centuries BC, were already considered by some of the first scholars working on the subject to be the result of interaction between the local population and Oriental or Greek settlers, despite the difficulties of locating on the map most of the Greek settlements in Iberia mentioned by the ancient sources, the absence of Greek sculptures from this period in the territory and the chronological mismatch between the alleged Greek models and the Iberian pieces dated to later periods. The statues found in the Greek settlement of Emporion, dated to the fourth and second centuries BC, apparently did not exercise a strong influence over the local communities of the surrounding area, which did not produce sculpture during that period (Chapa 2009: 77-8; Noguera 2003: 197).

From the arrival of the Roman troops in 218 BC to the end of the conquest in the final years of the first century $\mathrm{BC}$, statues show transformations that can be linked to a process 


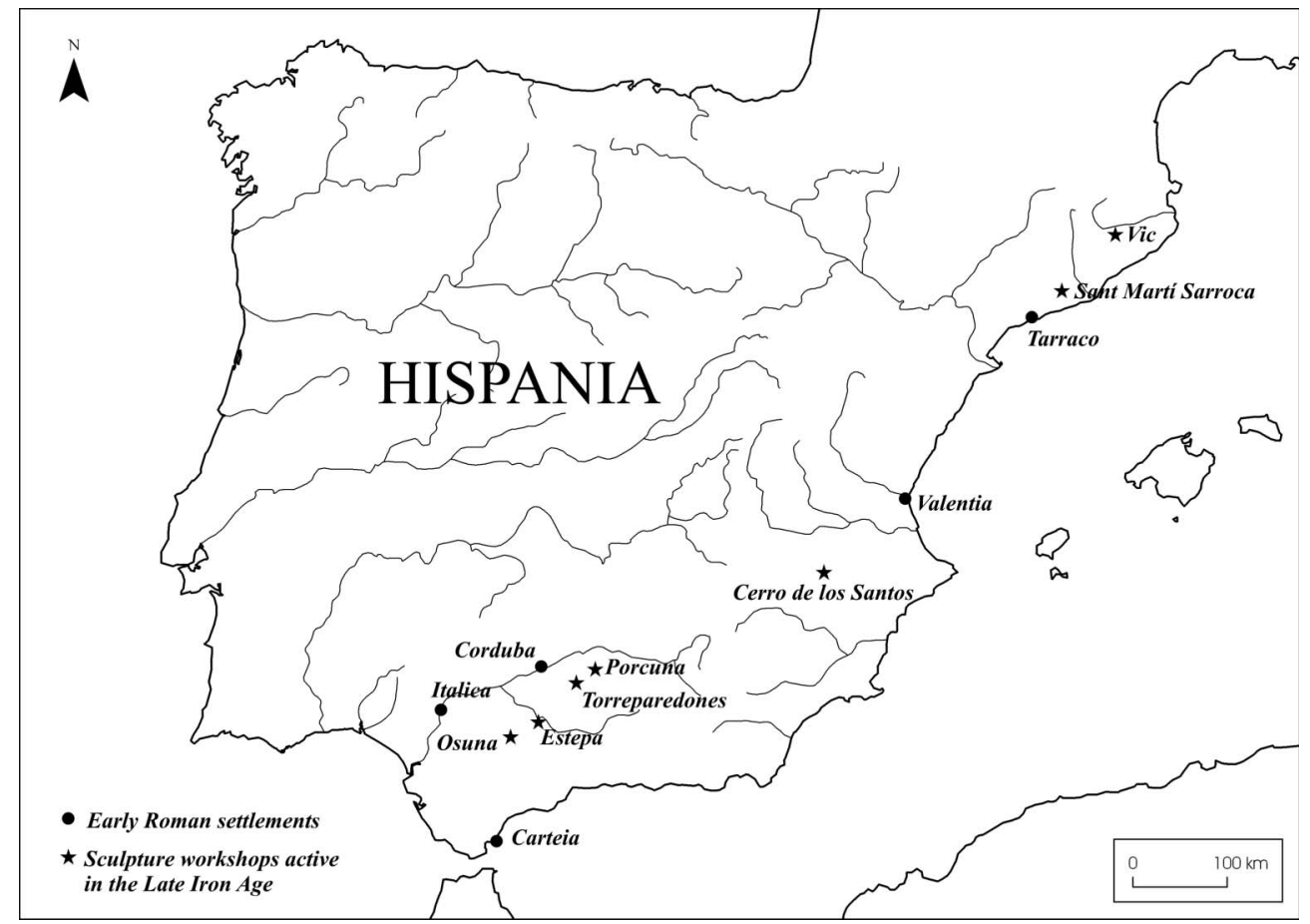

Figure 1 Map of the Iberian Peninsula showing sculpture workshops active in the Late Iron Age and early Roman settlements (base map courtesy of Trabajos de Prehistoria, http://tp.revistas.csic.es).

of social change and colonization. However, it is important to point out that these pieces are part of the production of local workshops (mainly Osuna/Estepa, Porcuna, Vic/San Martí Sarroca, Cerro de los Santos and Torreparedones), which were, in the most significant cases, active before the conquest (Noguera 2003: 197; Rodríguez Oliva 2001-2: 308). In contrast, the first Roman settlements on the Iberian Peninsula (Corduba, Italica, Carteia, Valentia, Tarraco) have not yet yielded evidence of similar importance (Beltrán 2009: 20). A further implication is that we must assume that no Italic sculptors were regularly working on the Iberian Peninsula and that local workshops did not have direct access to their supposed models of Roman statuary, since it has been impossible to discover statues imported from Greece and Italy during the Late Republic. Nevertheless, individual examples that could have left no trace in the archaeological record cannot be completely ruled out, for example in towns such as Italica, Corduba and Carthago Nova (Beltrán 2009: 20; Noguera 2003: 166).

If artisans seem to have been local, ambivalence arises when their potential clients are considered. The question reappears regularly in the Spanish literature, when archaeologists and art historians face the question of interpreting the sculptures as the result of the integration of certain Roman modes of sculptural representation into the local taste or as commissions for some types of statues (such as funerary lions and togati) given to native craftsmen by Italic immigrants (e.g. Pérez 1999: 15; Uroz 2008: 477). It is also important to bear in mind contexts of use, since this collection of sculptures mainly belongs, like their 
local predecessors, to specific sacred environments (cemeteries and suburban sanctuaries) located outside the city walls, and not to secular private or public urban spaces, places where statues would also have been displayed during the early Empire.

The second century BC witnessed a new concept of monumentality in local sanctuaries such as Cerro de los Santos (Montealegre del Castillo, Albacete), La Encarnación (Caravaca de la Cruz, Murcia) or La Luz (Verdolay, Murcia). Their temples may resemble Italic cultic buildings in their ground plans and decoration of Ionic and Tuscan capitals, terracotta panels and figures, even though they look very non-Italic in other respects, such as their location in an eccentric position outside the axis of the sacred space (temenos) in the case of La Encarnación or the absence of the compulsory podium in both Cerro de los Santos and La Encarnación sanctuaries (Ramallo 1993, 2003: 126-9; Ramallo et al. 1998). Customary ex -voto figurines (a 'double' of the worshipper in stone?) were placed on the benches of these sanctuaries by locals and perhaps Italic immigrants (Uroz 2008: 473). In fact, in Cerro de los Santos traditional types of statues offered by the worshippers in the fourth and third centuries BC (couples, standing males, sitting and standing women) were still considered appropriate in the second and first centuries BC, especially in the case of female representations (Plates 1a and 1b). Despite the influence of Roman colonization, people performing rituals in the sanctuary still included among their offerings the characteristic large stone figures, in contrast to the small terracotta or bronze statuettes common in the sanctuaries of central Italy. Statues were carved according to local techniques and made use of traditional raw materials - limestone and soft sandstone - to be later covered with stucco and painted. Among the preferred representations it was still possible to find archaic-looking standing women with complex hairstyles, long robes, rounded caps, mitres and diadems, as well as opulent necklaces and earrings, and holding a characteristic ritual vase (well represented among the ceramic finds from the site) or sitting women (Plates 2a and 2b).

However, some figures of standing men display certain objects worn by Roman citizens, such as calcei, a toga or a bulla. It has been noted that on four of these statues the Republican toga exigua was worn in the fashion of a Greek himation or a Roman pallium and that some of them have their head covered (capitibus velatis), a symbol of the sacredness of the ritual performed by the worshipper, according to iconographic types commonly found in the sanctuaries of central Italy during the fourth and second centuries $\mathrm{BC}$, although in Italy these figures are normally smaller than those from Cerro de los Santos. Other novelties include the inscription of the name of the worshipper or his community in the Iberian or Latin alphabet on some of these togati (Plate 3) and the growing interest in acquiring increasingly typological portraits, a trait that has been connected to Italic Hellenistic statuary, a prelude to the individual portraits produced in the second half of the first century BC (Plate 4). These bilingual images that made simultaneous use of traditional and new symbols shared the sacred space of the sanctuaries with almost aniconic stone images, traditionally linked by scholars to the Punic substratum of the area, not only in Cerro de los Santos, but also in sanctuaries such as Cigarralejo, La Bobadilla, Torre o Cortijo de Benzalá, La Encarnación and Torreparedones (Noguera 1994: 204-7, 1998: 451, 2003: 159-60, 180-1; Uroz 2008: 476), although a connection with Italic ancestor cults cannot be completely ruled out (Jiménez 2007; Uroz 2008: 477-8). 


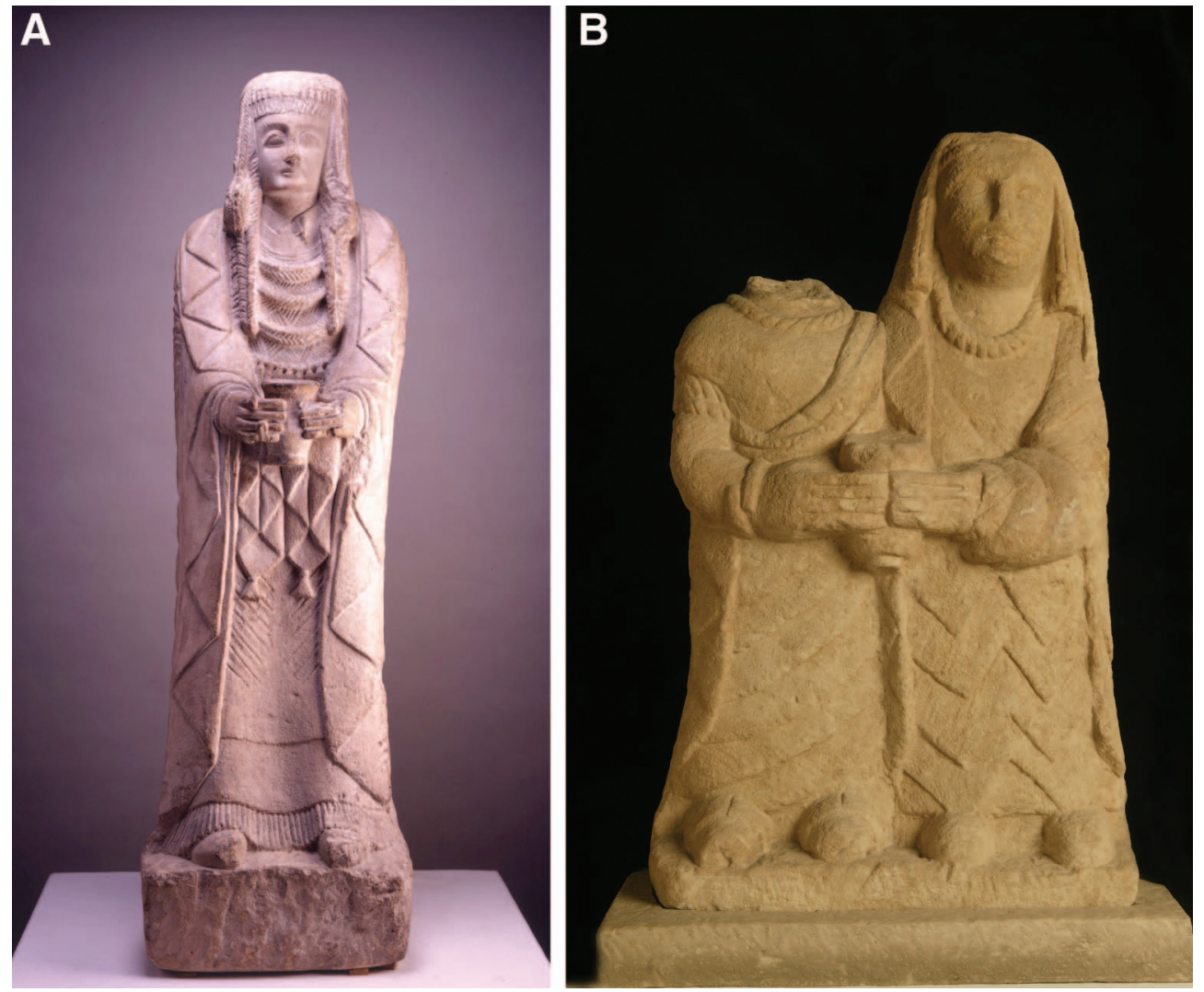

Plate 1 (a) Woman bringing an offer (the so-called Gran dama oferente), dated to the fourth century BC. From Cerro de los Santos, Montealegre del Castillo, Albacete (height $=135 \mathrm{~cm}$; width $=39 \mathrm{~cm}$ ). (b) Group of worshippers, dated to the second century BC. From Cerro de los Santos, Montealegre del Castillo, Albacete (height $=63 \mathrm{~cm}$; width $=37 \mathrm{~cm}$; photo Miguel Ángel Otero). (Both images from the Archive of the Museo Arqueológico Nacional, Madrid, Spain. Inv. numbers: 3500 and 3508 , reproduced with permission).

A taste for continuity and change is also the most prominent pattern in the funerary sculpture produced at this time. The typical pre-Roman burial consisted of a small hole in the ground containing a painted cinerary urn covered with a bowl and accompanied by ceramic cups. Very few of them were decorated with statues or reliefs on the surface. After the Roman conquest, monumental tombs were still part of a funerary landscape that changed particularly during the second half of the first century $\mathrm{BC}$ with the introduction of new monumental types from the Italic peninsula and a new arrangement of the sacred space along the roads leading out from the settlements. Images of bulls, rams and especially lions that probably adorned different types of funerary monuments were prominent in Iberia from the first representations in stone. They remained a popular choice throughout the Late Republic, both in the north (fragments from Can'Olivé, Cerdanyola, Barcelona; Mas Castella, Gerona) (Rodá 1998: 268-9) and in the south (at sites such as Castulo, Gadir and Carissa Aurelia) (Chapa 1985; Pérez 1999: 16; Rodríguez Oliva 2003). However, ways of understanding animal images in stone were reworked 

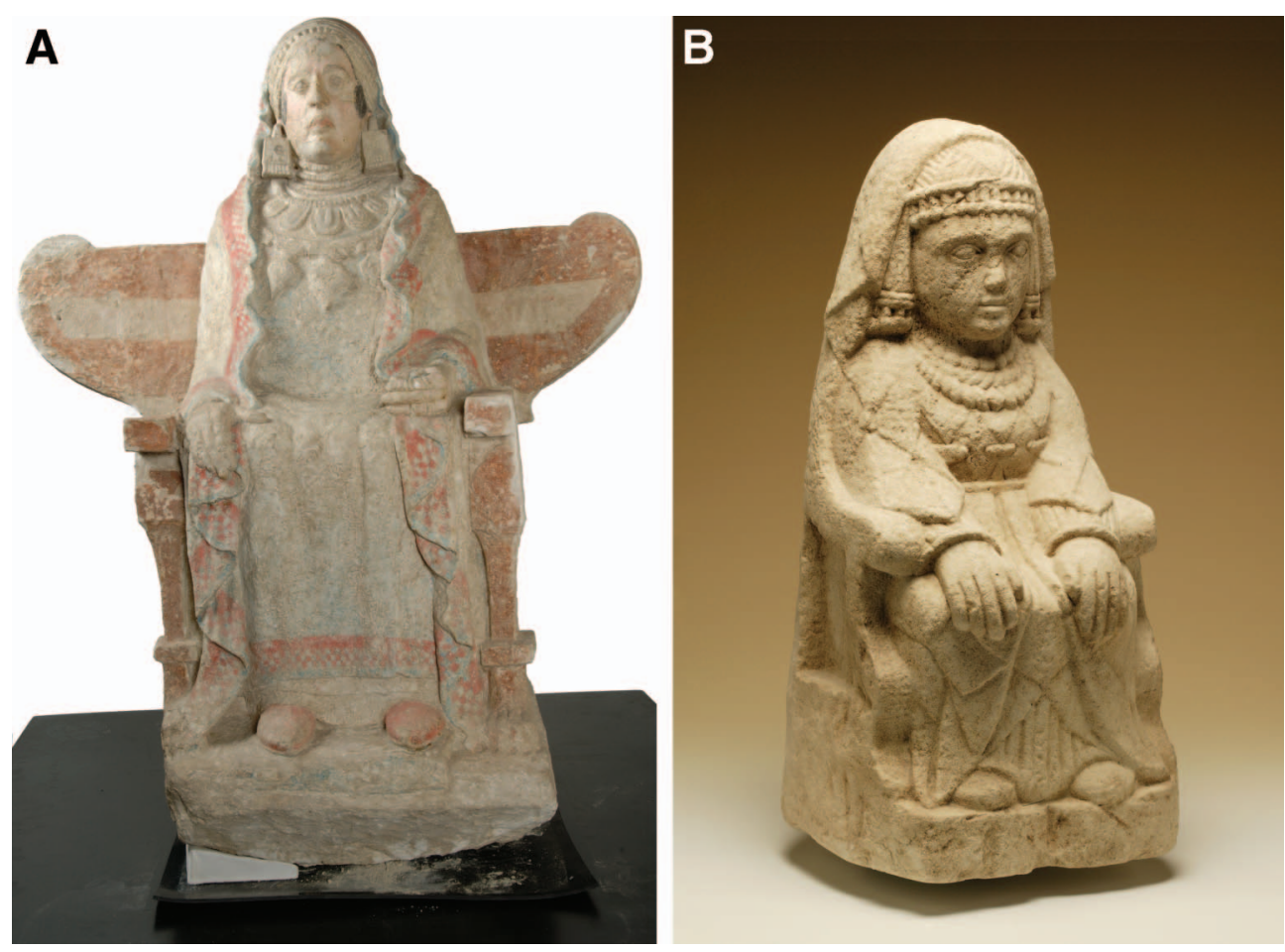

Plate 2 (a) The so-called 'Lady of Baza' (Dama de Baza) dated to the first half of the fourth century BC. From the cemetery of Baza, Granada (height $=133.5 \mathrm{~cm}$; width $=108 \mathrm{~cm}$; photo Ángel Martínez Levas). (b) Sitting woman, dated to the third-second century BC. From the sanctuary of Cerro de los Santos, Montealegre del Castillo, Albacete (height $=40 \mathrm{~cm}$; width $=18.5 \mathrm{~cm}$; photo Miguel Ángel Otero). (Both images from the Archive of the Museo Arqueológico Nacional, Madrid, Spain. Inv. numbers: 1969/68/155/123A and 7601, reproduced with permission).

between the second century BC and the first years of the Empire. A statue from Obulco (modern Porcuna), which probably depicts a feline, combines the Hellenistic iconographic type of lion with a victim under its paw, known in the south of the Iberian Peninsula at the time (Chapa 1985: 140-1; Pérez 1999: 15), with the depiction of a cultic figurine, a head above a squared section (a so-called 'hermaic' pillar; see Plates 5a and 5b). Mixing the funerary lion - with a long series of ancient prototypes in the region - and a hermaic pillar, a form that originated in Greece and was later appropriated by the Romans, and which was considered to have apotropaic characteristics, is an original combination not found in other regions of the classical world including, of course, Italy (Aranegui 2004; Beltrán and Loza 2005; Noguera and Rodríguez Oliva 2008: 381).

Two further examples dated to the Late Iron Age that use typical 'Iberian' funerary animals to represent characteristically 'Roman' religious sacrificial practices are especially interesting. A small figure of a bull found at Ronda la Vieja (Málaga), possibly used as a votive offering in a sanctuary, carries the dorsuale, the dorsal band on the back that identified the animal as a sacrificial beast in Roman contexts (Luzón and León 1971: 24750; Rodríguez Oliva 1996: 18, 2001-2: 313; see Plate 6). The second is not a free-standing sculpture, but a relief from Estepa that was probably a fragment from the decoration of 


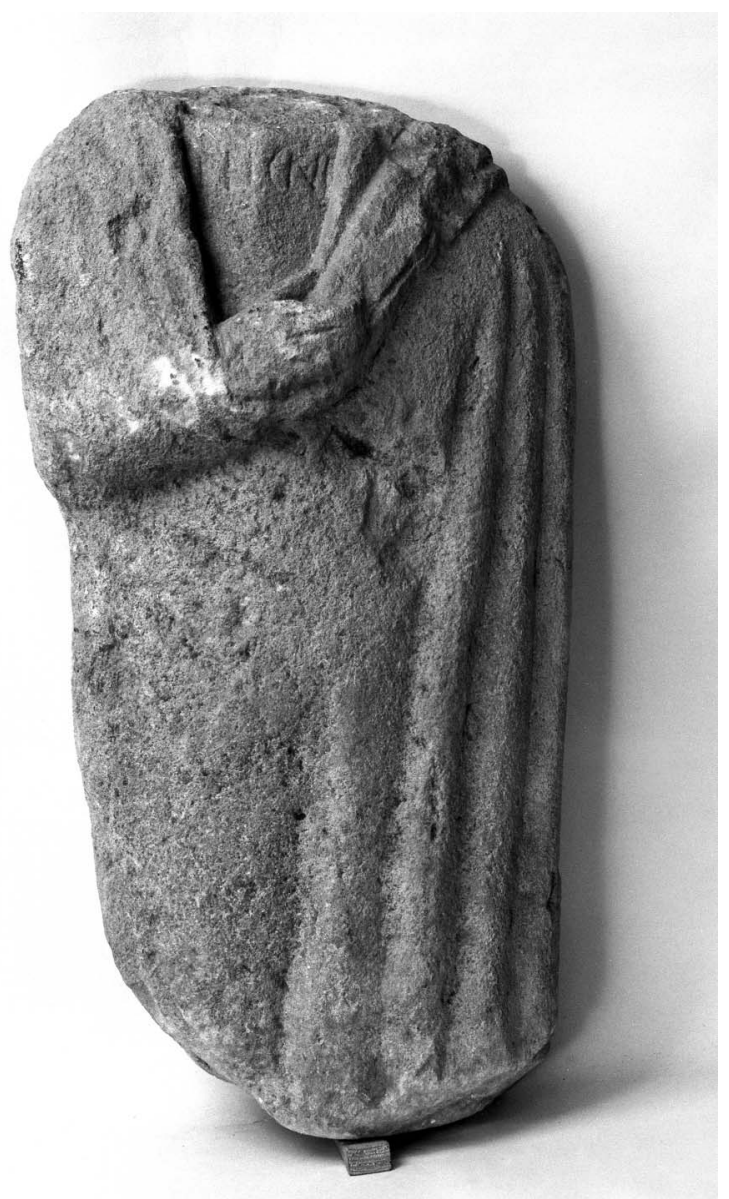

Plate 3 Togatus with Latin inscription across his breast L.LIC(I)NI, dated to the first century BC. It is an ex-voto or possibly image of Lucius Licinius, found at the sanctuary of Cerro de los Santos, Montealegre del Castillo, Albacete (height $=63 \mathrm{~cm}$; width $=32 \mathrm{~cm}$; photo Gisela Fittschen-Badura, D-DAI-MAD-FIB-R-020-84-01, reproduced with permission).

a tower tomb. It makes use of the traditional conventionalisms found in other Iberian carvings, but depicts a ritual scene that is also present in Roman monuments: the sacrifice of a ram before an altar, unfortunately erased in modern times. The piece was found in the late eighteenth century next to a cistern, together with coins, tegulae, bricks and another fragment of a tomb relief perhaps representing two first-century BC Roman legionaries (García y Bellido 1949: 404; Beltrán 2009: 37; Noguera 2003: 169; Noguera and Rodríguez Oliva, 2008: 411-12; Quesada 2008: 17-18; see Plate 7).

Fragments of other monuments, such as those found at Osuna, depict, however, local rituals related to offerings and libations. Other representations from the same site have been interpreted as representations of traditional funerary games (including music, gladiatorial games and fights between animals and men) in honour of the deceased, such as those that, according to the ancient sources, were performed by local populations on 


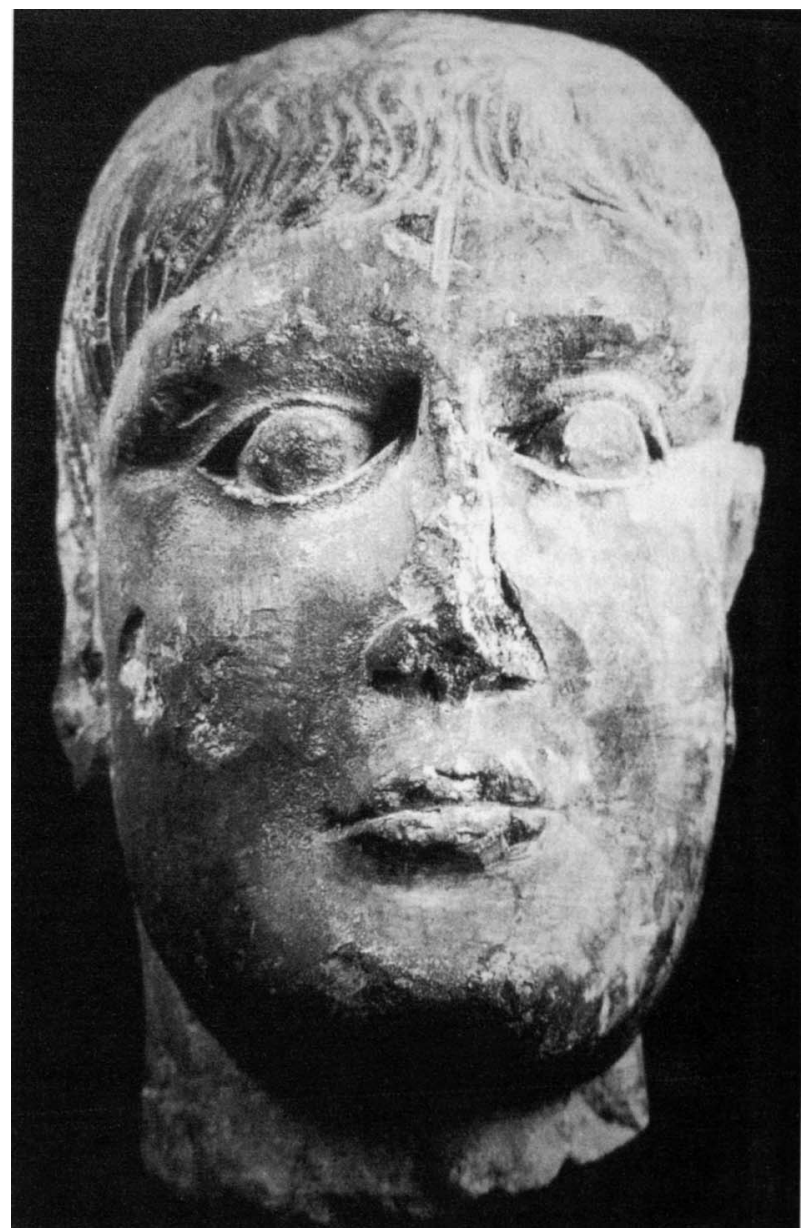

Plate 4 Male head, dated to the second BC, found at the sanctuary of Cerro de los Santos, Montealegre del Castillo, Albacete (height $=27 \mathrm{~cm}$; width $=17.8 \mathrm{~cm}$; from Noguera 2003: 180, fig. 33, reproduced with permission).

special occasions (Livy 28.21; Appian, Ib. 75) (Beltrán 2009: 25; Beltrán and Salas 2002: 246-8; Bendala 2007: 32-4; León 1981: 184-92, 1998: 97-106; Noguera and Rodríguez Oliva 2008: 387-94). These images are a mixture of 'modernity' and 'tradition'. They are a combination of new and old-fashioned items like the Iberian sword (falcata) of a warrior from Osuna, a region where Iron Age finds of falcatas are actually very scarce (Plate 8), or the decorated belt buckle worn by a flute player from the same town, which recalls pieces from the fourth century BC (Plate 9). They are an amalgamation of traditional and new elements, as can be seen in the image of individuals wearing only some elements of the Roman uniform (lorica or body armour, ocreae or greave and caligae or military sandals) in an earlier monument from the same site (León 1981: 191; Noguera 2003: 162-3; Quesada 1997).

Noguera (2003: 196) has described these practices as a fractional emulation of new motifs from Roman art. According to Rodríguez Oliva (1996: 14, 2001-2: 308), the bilingual nature of these sculptures made it possible for local workshops to produce pieces 

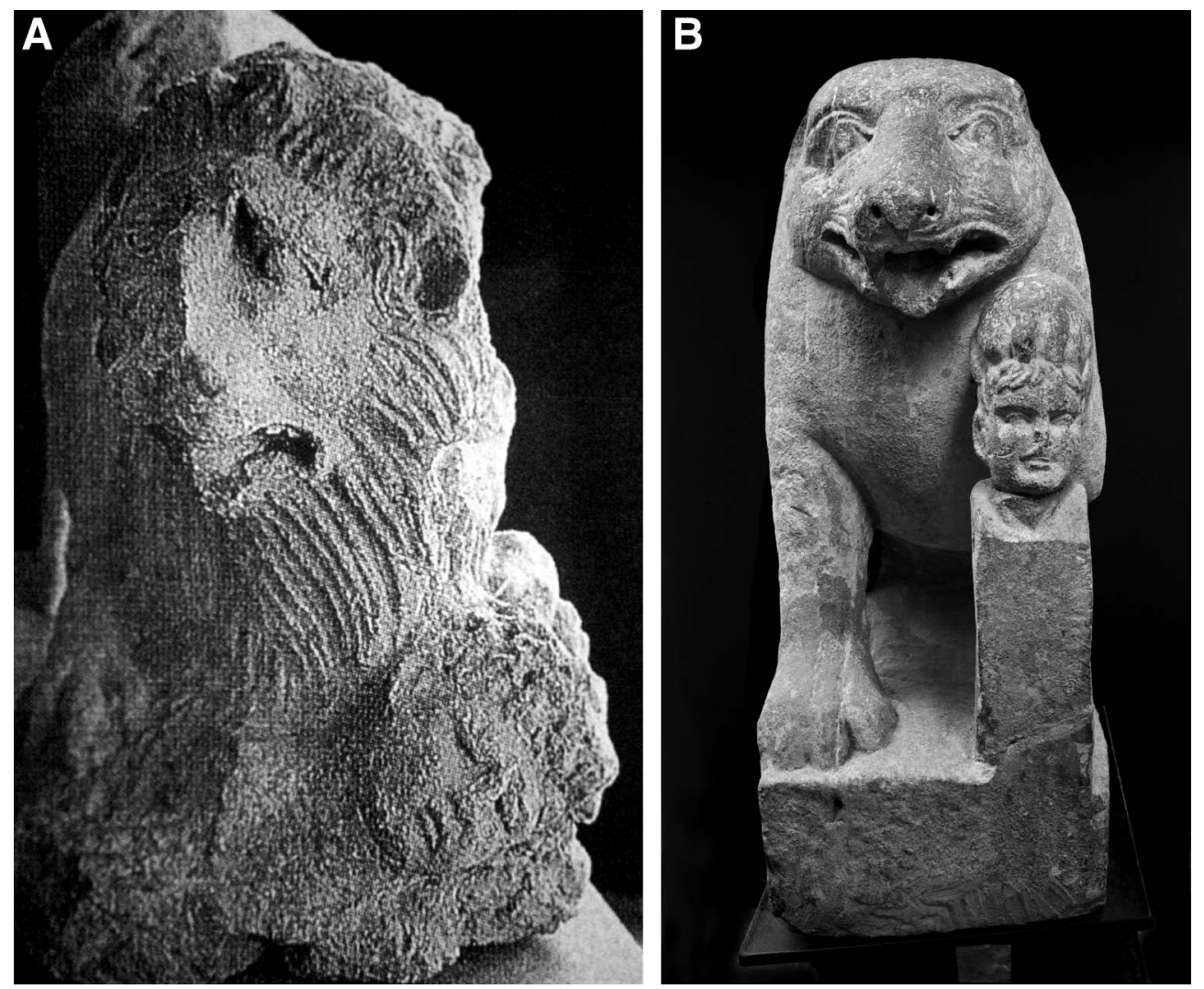

Plate 5 (a) Lion with head under his paw, dated to the first century BC, from Alcolea del Río, Sevilla (height $=60 \mathrm{~cm}$; width $=42 \mathrm{~cm}$; from Noguera 2003: fig. 34, reproduced with permission). (b) Representation of a feline with an herma under his paw, dated to the first century BC, from Porcuna, Jaén (height $=79 \mathrm{~cm}$; width $=70 \mathrm{~cm}$; photo Peter Witte, D-DAI-MAD-WIT-R-076-93-16, reproduced with permission).

commissioned by Roman settlers and to satisfy the local demand for 'Roman-like' figures. Interestingly enough, the need for these 'traditional-looking' interpretations of Roman art would not completely disappear during the early Empire in some regions of southern Iberia, where figures carved in local soft stone coexisted in the same settlements with sculptures identified by archaeologists as unequivocally Roman.

\section{The 'third space'}

Is it possible to go any further in the analysis of hybridity in archaeology? Is the study of hybridity in this field condemned to patiently listing the elements we perceive as belonging to two different cultures, in our case 'Iberian' and 'Roman'? Concerns about essentialist models of hybridism seen as the outcome of straightforward fusion have been expressed in relation to several studies of ancient colonialism (Gosden 2004: 60, 69; van Dommelen 2006: 138; Wallace-Hadrill 2008: 27-8). A possible alternative is to 


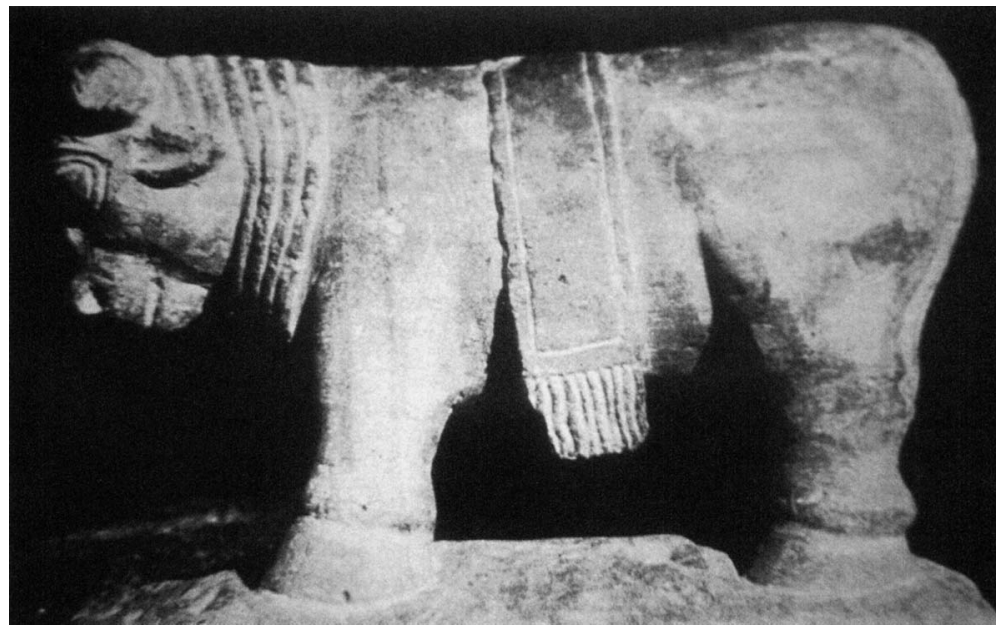

Plate 6 Bull covered with a dorsuale, dated to the first century BC, from Ronda la Vieja, Málaga (height $=33.5 \mathrm{~cm}$; width $=33.5 \mathrm{~cm}$; photo José María Luzón, from Luzón and León 1971, plate 11, reproduced with permission).

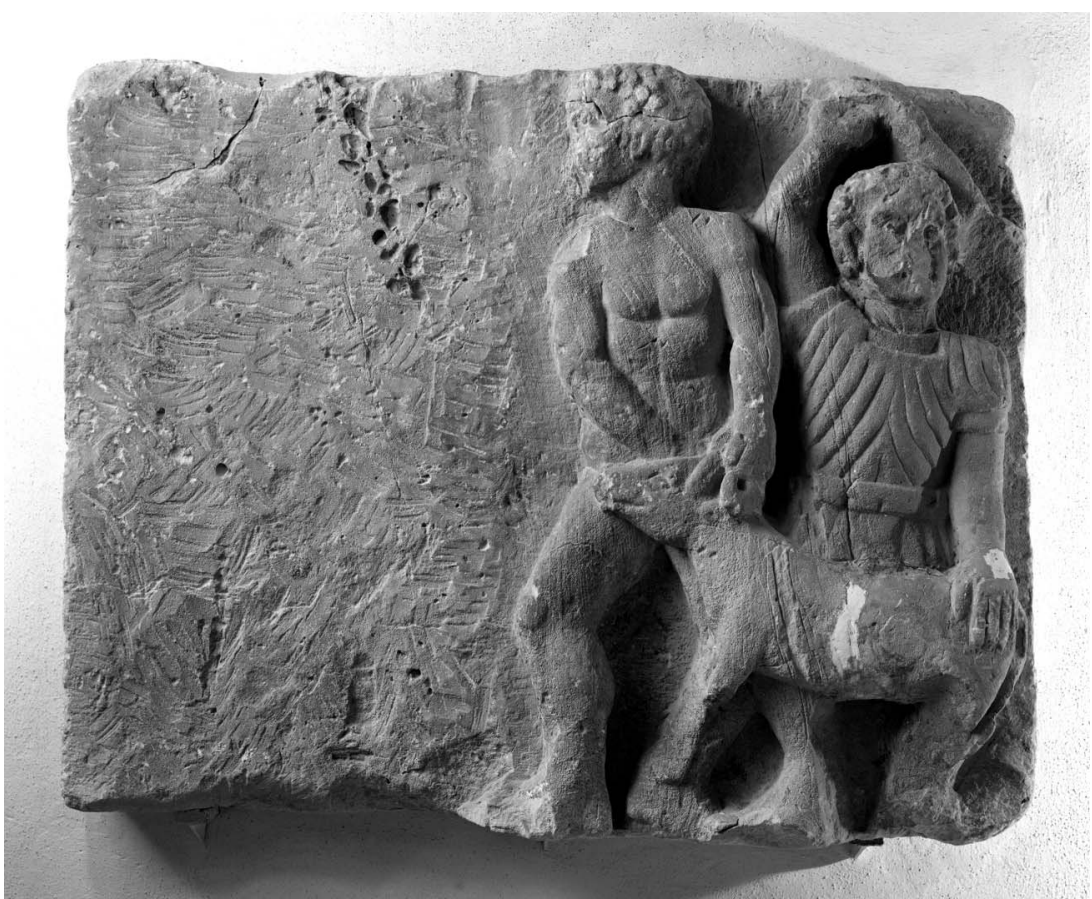

Plate 7 Sacrifice scene, dated to the first century BC, from Estepa, Sevilla (height $=104 \mathrm{~cm}$; width $=83 \mathrm{~cm}$; photo Peter Witte, D-DAI-MAD-WIT-R-053-79-17, reproduced with permission).

study hybridization in the postcolonial sense as introduced by Bhabha (1994) and to explore the relevance of this model for archaeology (van Dommelen 1998: 32, 2006: 136). 


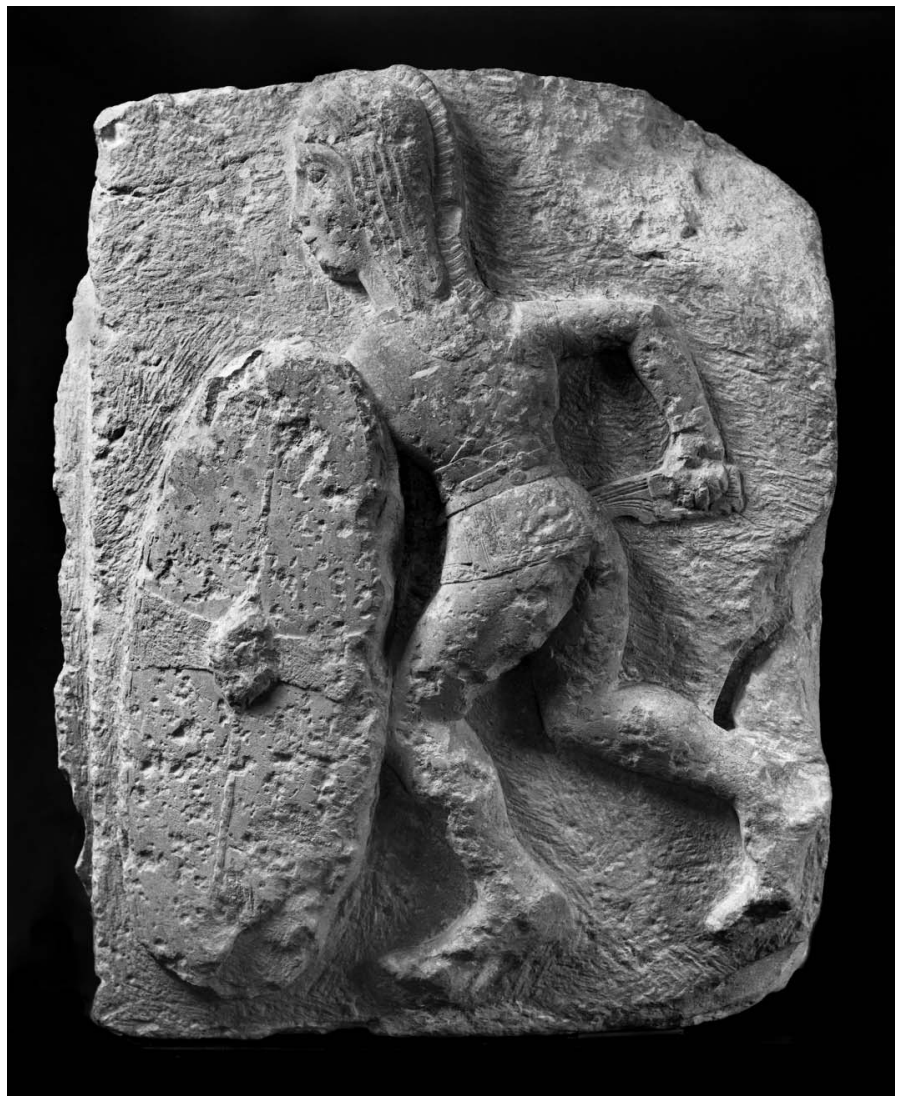

Plate 8 Warrior, dated to the second half of the third to second century $\mathrm{BC}$, found in Osuna, Sevilla (height $=69 \mathrm{~cm}$; width $=55 \mathrm{~cm}$; photo Peter Witte, D-DAI-MAD-WIT-R-052-93-01, reproduced with permission).

The problem of seeing hybridity as a result of contacts in multicultural scenarios is that it reproduces the creation of a classificatory grid that is closely linked to the notion of cultural purity. Williams explains this point in connection with that concept in an article on ethnicity and the nation: '[t]he starting point for the definition of purity is not, therefore, some objective point at which "real" purity, or for that matter, authentic culture, existed, but rather the classificatory moment of purification and the range of issues that motivate its invention' (Williams 1989: 429). The definition of the 'pure hybrid' is therefore dependent on the establishment of the limits of a model of 'pure culture'. Both the 'pure' and the 'hybrid' can be seen in this view as the result of social processes of classification that allow the 'hybrid', with the passage of time, to be considered precisely as a standard of purity and to become the source for the creation of new 'hybrids' (Kapchan and Strong 1999: 247; Stross 1999: 265; van Dommelen 2001: 75-82).

Bhabha links these representations of the diversity of cultures to Western connoisseurship and the 'knowledge-power' machinery involved in the location of cultures in a universal time-frame. Cultural diversity is appreciated, but only as long as it is possible to place alien cultures in a Western universalist grid that, paradoxically, 'masks ethnocentric 


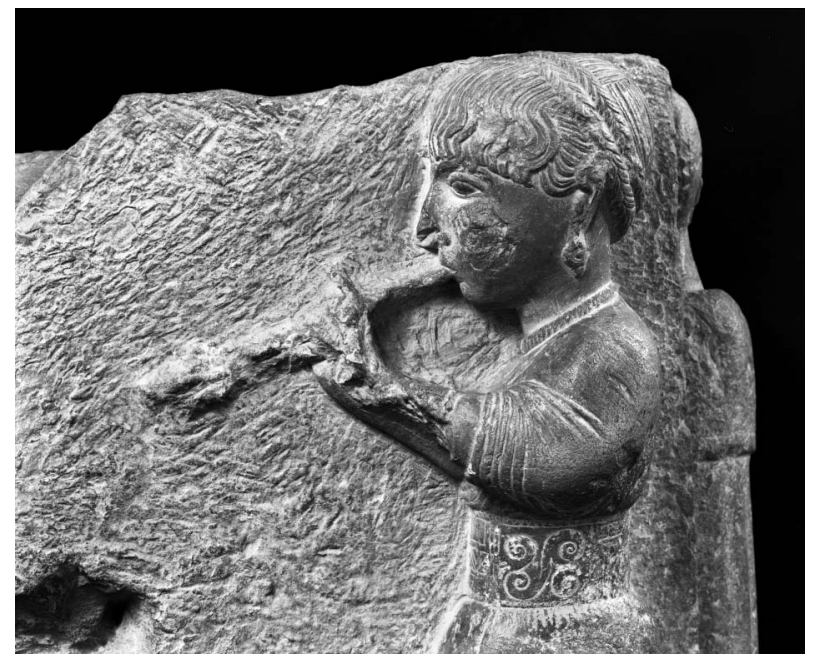

Plate 9 Detail of a flute player taking part in a procession, dated to the second half of the third to second century BC, found in Osuna, Sevilla (height $=60 \mathrm{~cm}$; width $=50 \mathrm{~cm}$; photo Peter Witte, DDAI-MAD-WIT-R-053-93-05, reproduced with permission).

norms, values and interests' (Bhabha 1990: 208). Similar positive views of multiculturalism can be traced in archaeological discourses on the expansion of Roman hegemony across the Mediterranean, with a careful mapping of archaeological cultures labelled, incidentally, with the names given by the ancient sources to a diverse array of conquered peoples, e.g. Bastetani, Oretani, Turdetani, etc., only to certify their final assimilation after a brief phase of hybridization - into Roman culture.

Bhabha also introduces the concept of 'cultural difference' associated with liminal spaces, which can be seen as an alternative to the notion of the diversity of cultures that has become the epistemological object of archaeological knowledge. It is in the spaces located on the borderline of various forms of culture that the "process of signification through which statements of culture and on culture differentiate, discriminate and authorise the production of fields of force, reference, applicability and capacity' takes place, according to Bhabha (1994: 34). Discourses on cultural hegemony require the establishment and iteration of limits in order to be effective, the declaration of divisive forms of identification. The articulation of hegemonic forms of Greek and Roman identities depended on alternative or antagonistic images of the barbarian (Hall 1989; Jiménez 2008: 25-6; Thollard 1987), which were partial representations of the Other or 'metonymies of antagonism', as Bhabha (1994: 29) calls them.

Borrowing the notion of 'cultural translation' from Walter Benjamin (1969 [1923]), Bhabha (1990: 209-10) suggests that all forms of culture are related to each other through their signifying or symbolic activity. This relation is mediated by a process of translation, which creates, however, a space in colonial representation that is open to contention and ambivalence (Bhabha 1994: 33). Cultural translation is a process of repetition and imitation on the part of the colonized, but in the very same act of domination the language of the master becomes hybrid, because interpretation is never a mere act of 
communication. The 'I' and the 'you' designated in the statement must go through what Bhabha describes as a 'third space' of enunciation for the production of meaning. This third space 'represents both the general conditions of language and the specific implication of the utterance in a performative and institutional strategy of which it cannot "in itself" be conscious' (Bhabha 1994: 36). But this unconscious relation introduces ambivalence into the act of interpretation in a scenario where meanings and values are (mis)read or signs are (mis)appropriated and in that way modified and rewritten (Bhabha 1994: 34). ${ }^{2}$ Because the 'original' is always open to translation, reproduction and representation, it can never reach an ideal moment of complete meaning or being. It is then precisely the way cultures have of producing meaning that makes them decentred structures (Bhabha 1990: 210), while at the same time these 'shifting margins of cultural displacement' are a powerful tool for blurring binary discourses and essentialist notions of culture, the nation (Bhabha 1994: 21) or the hybrid itself.

What Bhabha adds to dual models of cultural bilingualism is a reference to Mikhail Bakhtin's concept of 'heteroglossia' (raznorečie, raznorečivost or 'different-speech-ness'), which refers to the coexistence of distinct varieties within a single linguistic code as a consequence of the set of conditions (social, historical and psychological) governing the meaning of any utterance at a given time and place and the 'differing individual voices that flourish under such conditions' (Bakhtin 1981: 263). The important point to be made here, therefore, is not that in colonial situations the image of the colonizer and the colonized is often opposed in binary 'Orientalist-type' discourses and that the hybrid is bilingual or able to be competent in both cultural 'languages', 'Roman' and 'Iberian'. It is the fact that even within a single linguistic code (and, we could add, within the symbolic meaning of material culture), language stratifies into many voices or social dialects that are dependent on variants such as context, groups that share a certain behaviour, age groups, generations, occupational groups, discourses of the authorities and so on. These multiple voices have meaning only as part of a greater whole and are understood as a consequence of constant interaction of meanings, which can potentially condition each other.

Hybridization, according to the Russian philologist's study of discourse in the novel, is 'a mixture of two social languages within the limits of a single utterance, an encounter, within the area of utterance, between two different linguistic consciousnesses' (Bakhtin 1981: 358). He goes further in differentiating unconscious hybridity that is present in any living language and tends towards fusion and intentional hybridity where two points of view are set dialogically against each other, but not mixed (Bakhtin 1981: 358-66; Young 1995: 20-2). In the 'intentional hybrid' one linguistic consciousness represents and the other is represented: it is 'precisely the perception of one language by another language, its illumination by another linguistic consciousness' embodied in the author of the 'utterance' (Bakhtin 1981: 359). According to Bakhtin, the important activity of the intentional hybrid 'is not only (in fact not so much) the mixing of linguistic forms - the markers of two languages and styles - as it is the collision between differing points of view on the world that are embedded in these forms' (1981: 360). These ideas provide a new way of interpreting statues such as those discussed here, provincial productions that do not 'adjust' fully to Roman standards, which partially recreate Roman items according to a local logic in sanctuaries and cemeteries that were sometimes in use well before the Roman conquest. These sculptures show us a representation of Rome and of pre-Roman 
traditions simultaneously in a local language and in a 'single utterance'. The images they convey are meaningful in a context of heteroglossia in which, for example, contemporary depictions of female dress resemble local prototypes, while the men are wearing togas. Cultural identity should therefore be understood not as an essence but rather as a positioning that makes meaning possible (Hall 1990: 224, 230) - what Wallace-Hadrill (2008: 5-6) has termed 'cultural triangulation'. Hybridization in this sense becomes a cultural practice to explain a process in which people, rather than reified notions of culture, regain an active role in cultural encounters (Bourdieu 1977; van Dommelen 2006: 138-9).

If sculptures like those studied in this article can be better understood as statements about cultural meaning and cultural difference than as a composite of 'Iberian' and 'Roman' traits, then what is important is not tracing the origin of every single piece of the pastiche and dismissing the result as a failed copy. What is crucial is to understand the meaning of the 'quote' made by players and its role in building up material discourses of difference and similitude 'through which the Other penetrates the formation of "sameness"، (Amselle 1998: x; Osborne and Vout 2010: 240). Roman statuary was partially appropriated and worked anew through an original translation of symbols using local techniques and what were considered to be the appropriate spaces for representation according to local practices. They made sense in the context of the province by means of a simultaneous relational reference to what they were not (in an agonistic relation to certain sculptural productions in Italy) and to what they were similar to, including representations familiar to both Italian settlers and local populations through an active engagement with tradition. In this sense, the enunciation of cultural difference problematizes not only the binary division between the colonizer and the colonized but also those that present a neat split in antiquity between the past and the present or heritage and innovation. Those statues were modern and traditional at the same time and in signifying the present (back then), they relocated, re-inscribed and translated certain things in the name of tradition in a probable 'strategy of representing authority in terms of the artifice of the archaic' (Bhabha 1994: 35). This collection of pieces also shows how metonymic representations or the partial presence of the Other work in both directions in colonial contexts, carving out an image of the barbarian in the metropolis as much as creating partial representations of Rome in the provinces according to a local logic. The latter are worth studying no less than Graeco-Roman discourses on conquered peoples.

\section{Conclusion: beyond the classificatory moment of hybridization}

In a cultural landscape of pure hybridism, there is no point in establishing the border that something or someone has to cross to become impure but there is certainly much to be gained from analysing how discourses on purity and hybridity were constructed in antiquity and our present way of explaining antiquity and positioning ourselves in relation to it. Every cultural form is hybrid in the sense that it derives its meaning from referential processes but hybridism can be considered as specifically connected to colonialism and even as a product of colonial power - the reverse of colonial representations, according to Bhabha (1994: 114). Roman hegemony was at least in part discursively constructed around notions of barbarism and civilization or humanitas (Gros 1998; Woolf 1998: 
54-60) and these representations of the Other were only viable as long as the Other remained different enough to justify their subordinated position in the colonial society. The ambivalence of colonial discourse revolves precisely around the desire to transform the Other into a recognizable individual, who is 'almost the same, but not quite' (Bhabha 1994: 86). This is the point at which the hybrid acquires the potential to destabilize or, at least, to transform the hegemonic model in the provinces by means of a process of cultural translation and the creation of a provincial stylized representation of Rome. We must nevertheless keep in mind that this model was imposed after a violent process of conquest and territorial expansion and that the Urbs as a model remained a pervasive image in Roman written discourses as well as in modern interpretations of provincial material culture as instances of failed imitation.

A different approach is therefore needed in order to understand how the symbols present in this collection of sculptures (traditional female dress and jewellery, traditional weapons, togas, Roman armour, animals dressed for sacrifice) were creating a new concept of what it was to be Roman in the provinces and how different pasts were interwoven in contexts with such strong connections to origins and ancestors as the sanctuary and the tomb. It is important to note that the place of enunciation was chosen in accordance with local practices (sculptures were displayed in their traditional scenario), even though the context was rapidly changing due to new forms of monumentalizing native sanctuaries and cemeteries at the end of the first century BC. Heteroglossia is, in that respect, an interesting metaphor for understanding not only the different 'cultural languages' that can be considered appropriate in different social contexts for different social actors but also how apparently discordant references (to Italy, to other Iberian sanctuaries, to practices traditional to a given site) in the same object can be built up in the naturalization of new meanings in the provinces through repetition.

Young has noted that hybridity 'operates according to the form of logic that Derrida isolates in the term "brisure", a breaking and a joining at the same time, in the same place: difference and sameness in an apparently impossible simultaneity' (1995: 26). Hybridism is fusion and rupture but not at random, as it builds up according to metaphors of similarity and difference, through metonymic representations of the part for the whole and through images of partial presence. In this metaphoric practice of substituting one term for another, the agents involved (sculptors and their patrons) explicitly express precious details about perceived external or internal similarities, tracing a path between hidden continuities, detecting underlying but essential relations, and establishing analogies between elements that may no longer have been considered contradictory (Gruzinski 2000: 187-8, 191).

\section{Acknowledgements}

I am very grateful to Peter van Dommelen, Robin Osborne, David Wengrow and Camilla Ruud for their comments on an earlier draft of this paper. I am also indebted to Irene Mañas, Juan Pimentel, Jesús Bermejo and Dougal Ainsley for their feedback and help during the writing process. Research funded by the Ministry of Education of Spain (EX2009-0172) and the European Social Fund (I3PDR-1-10). 


\section{Notes}

1 Note that subtle differences exist between the variations of the term: in this paper, I will use 'hybridism' to refer to the general concept and the two related terms 'hybridity' and 'hybridization' as references to, respectively, the condition of being and the process of becoming hybrid.

2 White's (1991) model of 'Middle Ground' has usually been favoured by historians and archaeologists, although it cannot be considered equivalent.

\section{References}

Ahmad, A. 1992. In Theory: Classes, Nations, Literatures. London: Verso.

Ahmad, A. 1995. The politics of literary postcoloniality. Race and Class, 36: 1-20.

Amselle, J.-L. 1998. Mestizo Logics: Anthropology of Identity in Africa and Elsewhere. Stanford, CA: Stanford University Press.

Anderson, B. 1991. Imagined Communities: Reflections on the Origin and Spread of Nationalism. London: Verso.

Appadurai, A. 1996. Modernity at Large: Cultural Dimensions of Globalization. Minneapolis: University of Minnesota Press.

Aranegui, C. 2004. Leones funerarios de época iberorromana: La serie asociada a las cabezas humanas. In Actas de la IV Reunión sobre escultura romana en Hispania (Lisboa 7-9 feb. 2002) (eds T. Nogales and L. J. Gonçalves). Madrid: Ministerio de Cultura, pp. 213-27.

Ashcroft, B., Griffiths, G. and Tiffin, H. 1998. Postcolonial Studies: The Key Concepts. London and New York: Routledge.

Bakhtin, M. 1981. The Dialogic Imagination: Four Essays (ed. M. Holquist). Austin: University of Texas Press.

Barth, F. 1989. The analysis of culture in complex societies. Ethnos, 54: 120-42.

Beltrán, J. 2009. Precedentes. In Arte romano de la Bética: Escultura (ed. P. León). Sevilla: Fundación Focus-Abengoa, pp. 17-39.

Beltrán, J. and Loza, M. L. 2005. El 'Oso de Porcuna': Una escultura funeraria excepcional de la Hispania Romana. Romula, 4: 163-76.

Beltrán, J. and Salas, J. 2002. Los relieves de Osuna. In Urso: A la búsqueda de su pasado (ed. F. Chaves). Osuna: Fundación de Cultura García Blanco, pp. 235-72.

Bendala, M. 2007. El arte ibérico en el ámbito andaluz: Notas sobre la escultura. In Actas del Congreso: Arte Ibérico en la España mediterránea (Alicante 24-27 de octubre 2005) (eds L. Abad and J. A. Soler). Alicante: Instituto Alicantino de Cultura 'Juan Gil-Albert', Diputación Provincial, pp. 21-38.

Benjamin, W. 1969 [1923]. The task of the translator: an introduction to the translation of Baudelaire's Tableaux Parisiens. In Walter Benjamin, Illuminations (ed. H. Arendt). New York: Schocken Books, pp. 69-82.

Bhabha, H. K. 1990. The third space. In Identity, Community, Culture, Difference (ed. J. Rutherford). London: Lawrence \& Wishart, pp. 207-21.

Bhabha, H. K. 1994. The Location of Culture. London: Routledge.

Bourdieu, P. 1977. Outline of a Theory of Practice. Cambridge: Cambridge University Press. 
Burke, P. 2009. Cultural Hybridity. Cambridge: Polity Press.

Chapa, T. 1985. La escultura ibérica zoomorfa. Madrid: Ministerio de Cultura.

Chapa, T. 2009. Influencias griegas en la escultura ibérica. In Huellas griegas en la Contestania Ibérica (eds M. Olcina and J. J. Ramón). Alicante: Museo de Alicante, pp. 76-84.

Clifford, J. 1988. The Predicament of Culture. Cambridge, MA: Harvard University Press.

Cohen, R. and Toninato, P. 2010. Introduction: the creolization debate: analysing mixed identities and cultures. In The Creolization Reader: Studies in Mixed Identities and Cultures (eds R. Cohen and P. Toninato). New York: Routledge, pp. 1-21.

Dueck, D. 2000. Strabo of Amasia: A Greek Man of Letters in Augustan Rome. London and New York: Routledge.

Friedman, J. 1997. Global crisis, the struggle for cultural identity and intellectual porkbarrelling: cosmopolitans versus locals, ethnics, and nationals in an era of dehegemonization. In Debating Cultural Hybridity (eds P. Werbner and T. Modood). London: Zed Books, pp 70-89.

Friedman, J. 1999. The hybridization of roots and the abhorrence of the bush. In Spaces of Culture: City - Nation - World (eds M. Featherstone and S. Lash). London: Sage, pp. 230-56.

García y Bellido, A. 1949. Esculturas romanas de España y Portugal. Madrid: Consejo Superior de Investigaciones Científicas.

Gikandi, S. 2005. Globalization and the claims of postcoloniality. In Postcolonialisms: An Anthology of Cultural Theory and Criticism (eds G. Desai and S. Nair). Oxford: Berg, pp. 608-34; originally published in South Atlantic Quarterly, 100(3): 627-58, 2002.

Gosden, C. 2004. Archaeology and Colonialism: Cultural Contact from 5000 BC to the Present. Cambridge: Cambridge University Press.

Gros, P. 1998. Le Barbare humanisé ou les limites de l'humanitas. In Images Romaines: Actes de la Table Ronde organisée à l'École Normale Supérieure (24-26 oct. 1996) (ed. C. Auvray-Assayas). Paris: Presses de l'École Normale Supérieure, pp. 143-59.

Gruzinski, S. 2000. El pensamiento mestizo. Barcelona: Paidós.

Hall, E. 1989. Inventing the Barbarian: Greek Self-Definition through Tragedy. Oxford: Clarendon Press.

Hall, S. 1990. Cultural identity and diaspora. In Identity, Community, Culture, Difference (ed. J. Rutherford). London: Lawrence \& Wishart, pp. 222-37.

Hannerz, U. 1987. The world in creolization. Africa, 57(4): 546-59.

Herskovits, M. J. 1966. The New World Negro: Selected Papers in Afroamerican Studies. Bloomington: Indiana University Press.

Jiménez, A. 2007. Culto a los ancestros en época romana: Los cipos funerarios de las necrópolis de Baelo Claudia (Bolonia, Cádiz). Archivo Español de Arqueología, 80: 75-106.

Jiménez, A. 2008 Imagines hibridae: Una aproximación postcolonialista al estudio de las necrópolis de la Bética. Madrid: Consejo Superior de Investigaciones Científicas.

Jones, S. 1997. The Archaeology of Ethnicity: Constructing Identities in the Past and Present. London: Routledge.

Kapchan, D. A. and Strong, P. 1999. Theorizing the hybrid. Journal of American Folklore, 112(445): 239-53.

León, P. 1981. Plástica ibérica e iberorromana. In La baja época de la cultura Ibérica. Madrid: José Esteban, pp. 183-202.

León, P. 1998. La sculpture des ibères. Paris: L'Harmattan. 
Lomas, F. J. 1996. Civilización y barbarie: A vueltas con la romanización. In La romanización en Occidente (eds. J. M. Blázquez and J. Alvar). Madrid: Actas, pp. 45-55.

Long, E. 1774. The History of Jamaica: Or, General Survey of the Ancient and Modern State of that Island; with Reflections on its Situation, Settlements, Inhabitants, Climate, Products, Commerce, Laws and Government, Vol. 2. London: Lowndes.

Luzón, J. M. and P. León. 1971. Esculturas romanas de Andalucía. Habis, 2: 233-50.

Noguera, J. M. 1994. La escultura romana de la provincia de Albacete (Hispania Citerior, Conventus Carthaginensis). Albacete: Instituto de Estudios Albacetenses; Diputación de Albacete.

Noguera, J. M. 1998. Nueva hipótesis interpretativa del santuario ibérico del Cerro de los Santos (Montealegre del Castillo, Albacete) en época tardorrepublicana a través del análisis de algunos exvotos esculturados de su depósito votivo. In Italia e Hispania en la crisis de la República romana: Actas del III Congreso Hispano-Italiano (Toledo, 20-24 de septiembre de 1993) (ed. J. Mangas). Madrid: Facultad de Geografía e Historia de la Universidad Complutense, pp. 44761.

Noguera, J. M. 2003. La escultura hispanorromana en piedra de época republicana. In De Iberia in Hispaniam: La adaptación de las sociedades ibéricas a los modelos romanos (ed. L. Abad). Alicante: Universidad de Alicante, pp. 151-208.

Noguera, J. M. and Rodríguez Oliva, P. 2008. Scultura ispànica in epoca repubblicana: Note su generi, iconografia, usi e cronologia. In Iberia e Italia: Modelos romanos de integración territorial (eds J. Uroz, J. M. Noguera and F. Coarelli). Murcia: Tabularium, pp. 379-453.

OLD 1982. s. v. Hybrida. In Oxford Latin Dictionary (ed. P. G. W. Glare). Oxford: Clarendon Press, p. 810 .

Osborne, R. and Vout, C. 2010. A revolution in Roman history? Journal of Roman Studies, 100: 23345.

Palmié, S. 2007. The 'C-word' again: from colonial to postcolonial semantics. In Creolization: History, Ethnography, Theory (ed. C. Stewart). Walnut Creek, CA: Left Coast Press, pp. 66-83.

Parry, B. 1987. Problems in current discourse theory. Oxford Literary Review, 9: 27-58.

Pérez, I. 1999. Leones romanos en Hispania. Madrid and Sevilla: Fundación Focus Abengoa.

Quesada, F. 1997. El armamento ibérico: Estudio tipológico, geográfico, funcional, social y simbólico de las armas en la cultura ibérica (siglos VI-I a. C.). Montagnac: Monique Mergoil.

Quesada, F. 2008. Armamento romano e ibérico en Urso (Osuna): Testimonio de una época. Cuadernos de los Amigos de los Museos de Osuna, 10: 13-19.

Ramallo, S. F. 1993. Terracotas arquitectónicas del santuario de La Encarnación (Caravaca, Murcia). Archivo Español de Arqueología, 64: 71-98.

Ramallo, S. F. 2003. Las ciudades de Hispania en época Republicana: Una aproximación a su proceso de 'monumentalización'. In De Iberia in Hispaniam: La adaptación de las sociedades ibéricas a los modelos romanos (ed. L. Abad). Alicante: Universidad de Alicante, pp. 101-49.

Ramallo, S. F., Noguera, J. M. and Brotóns, F. 1998. El Cerro de los Santos y la monumentalización de los santuarios ibéricos tardíos. Revista de Estudios Ibéricos, 3: 11-69.

Rodà, I. 1998. La difícil frontera entre escultura ibérica y la escultura romana. In Actas del Congreso Internacional Los íberos, príncipes de Occidente: Estructuras de poder en la sociedad ibérica (Barcelona 12-14 de marzo, 1998) (ed. C. Aranegui). Barcelona: Fundación La Caixa, pp. 265-73.

Rodríguez Oliva, P. 1996. Las primeras manifestaciones de la escultura romana en la Hispania Meridional. In Actas de la II Reunión sobre escultura romana en Hispania (Tarragona, 1995). Tarragona: Museu Nacional Arqueològic de Tarragona, pp. 13-30. 
Rodríguez Oliva, P. 2001-2. Sobre las esculturas ibéricas e ibero-romanas de los territorios malacitanos. Anales de Prehistoria y Arqueología, 17-18: 301-20.

Rodríguez Oliva, P. 2003. Esculturas zoomorfas de época romano-republicana de la provincia de Málaga. Mainake, 25: 321-57.

Rosaldo, R. 1989. Culture and Truth: The Remaking of Social Analysis. Boston, MA: Beacon.

Spengler, O. 1918-22. Der Untergang des Abendlandes: Umrisse einer Morphologie der Weltgeschichte. Wien and Leipzig: W. Braumüller.

Stewart, C. 1999. Syncretism and its synonyms: reflections on cultural mixture. Diacritics, 29(3): 4062.

Stewart C. 2007. Creolization: history, ethnography, theory. In Creolization: History, Ethnography, Theory (ed. C. Stewart). Walnut Creek, CA: Left Coast Press, pp. 1-25.

Stross, B. 1999. The hybrid metaphor: from biology to culture. In Theorizing the Hybrid (eds D. A. Kapchan and P. Strong). Journal of American Folklore, 112(445): 254-67.

Thollard, P. 1987. Barbarie et civilisation chez Strabon: Étude critique des livres III et IV de la Géographie. Paris: Belles Lettres.

Uroz, H. 2008. Religión en tiempos de transición: De Iberia a Hispania: Poder, control y autoafirmación. In Iberia e Italia: Modelos romanos de integración territorial (eds J. Uroz, J. M. Noguera and F. Coarelli). Murcia: Tabularium, pp. 465-92.

Vale de Almeida, M. 2002. 'Longing for oneself': hybridism and miscegenation in colonial and postcolonial Portugal. Etnográfica, 6(1): 181-200.

Van Dommelen, P. 1998. On Colonial Grounds: A Comparative Study of Colonialism and Rural Settlement in First Millennium BC West Central Sardinia. Leiden: Faculty of Archaeology, University of Leiden.

Van Dommelen, P. 2001. Cultural imaginings: Punic tradition and local identity in Roman Republican Sardinia. In Italy and the West: Comparative Issues in Romanisation (eds S. Keay and N. Terrenato). Oxford: Oxbow Books, pp. 68-84.

Van Dommelen, P. 2006. The Orientalizing phenomenon: hybridity and material culture in the Western Mediterranean. In Debating Orientalization: Multidisciplinary Approaches to Change in the Ancient Mediterranean (eds C. Riva and N. C. Vella). London: Equinox, pp. 135-52.

Wallace-Hadrill, A. 2008. Rome's Cultural Revolution. Cambridge: Cambridge University Press.

Webster, J. 2001. Creolizing the Roman provinces. American Journal of Archaeology, 105: 209-25.

Werbner, P. 1997. Essentialising essentialism, essentialising silence: ambivalence and multiplicity in the constructions of racism and ethnicity. In Debating Cultural Hybridity: Multi-Cultural Identities and the Politics of Anti-Racism (eds P. Werbner and T. Modood). London: Zed Books, pp. 226-54.

White, R. 1991. The Middle Ground: Indians, Empires, and Republics in the Great Lakes Region, 1650-1815. Cambridge: Cambridge University Press.

Williams, B. 1989. A class act: anthropology and race to nation across ethnic terrain, Annual Review of Anthropology, 18: 401-44.

Woolf, G. 1998. Becoming Roman: The Origins of Provincial Civilization in Gaul. Cambridge: Cambridge University Press.

Young, R. 1995. Colonial Desire: Hybridity in Theory, Culture and Race. London: Routledge. 
Alicia Jiménez is a postdoctoral research fellow of the Spanish Ministry of Education (Universidad Autónoma de Madrid) working at UCL (Anthropology Department) and Glasgow University (Archaeology, School of Humanities) as part of the 'Material Connections: mobility, materiality and Mediterranean identities' project, jointly directed by Peter van Dommelen, Bernard Knapp and Michael Rowlands. She is author of Imagines hibridae: una aproximación postcolonialista a las necropolis de la Bética (Madrid, 2008) and editor of Colonising a Colonised Territory (Rome, 2010, in Bollettino di Archeologia Online, 0). Her research interests include archaeological theory and the transition between the Iron Age and the Roman period on the Iberian Peninsula, with a special interest in topics such as social change and colonization, material culture in public and private contexts and the interaction between the past and the present in the creation of contemporary 'origin myths' in Spain. 